\title{
Application of a high-surface-area schwertmannite in the removal of arsenate and arsenite
}

\author{
J. Song $\cdot$ S.-Y. Jia $\cdot$ H.-T. Ren $\cdot$ S.-H. Wu $\cdot$ \\ X. Han
}

Received: 22 April 2013/Revised: 29 November 2013/Accepted: 16 February 2014/Published online: 4 March 2014

(C) Islamic Azad University (IAU) 2014

\begin{abstract}
Schwertmannite is a poorly crystalline Fe(III) hydroxide, which always shows high sorption capacities to pollutants. In this study, schwertmannite synthesized from the $\mathrm{Fe}^{3+}$ hydrolyzation method showed a hedgehog-like shape, with a specific surface area of $325.5 \mathrm{~m}^{2} \mathrm{~g}^{-1}$, which was much higher than that of the sphere-like schwertmannite synthesized from the $\mathrm{Fe}^{2+}$ oxidation method, with a specific surface area of $48.2 \mathrm{~m}^{2} \mathrm{~g}^{-1}$. The former was then used to evaluate its sorption performance to $\mathrm{As}(\mathrm{V})$ and $\mathrm{As}(\mathrm{III})$. Sorption of $\mathrm{As}(\mathrm{V})$ and $\mathrm{As}(\mathrm{III})$ could reach equilibrium in $200 \mathrm{~min}$, and the maximum sorption capacities of $\mathrm{As}(\mathrm{V})$ and $\mathrm{As}(\mathrm{III})$ were 182.86 and $45.50 \mathrm{mg} \mathrm{g}^{-1}$ at $\mathrm{pH}$ 3.0 , respectively, and 143.25 and $217.85 \mathrm{mg} \mathrm{g}^{-1}$ at $\mathrm{pH} 7.0$, respectively. Sorption capacity was dependent on $\mathrm{pH}$ and more $\mathrm{As}(\mathrm{V})$ adsorbed on schwertmannite at lower $\mathrm{pH}$, while As(III) sorption increased with the increase of $\mathrm{pH}$. Our results also indicated that the presence of sulfate reduced the sorption of $\mathrm{As}(\mathrm{V})$ from 85.4 to $67.6 \mathrm{mg} \mathrm{g}^{-1}$ as
\end{abstract}

J. Song · S.-Y. Jia $\cdot$ H.-T. Ren $\cdot$ S.-H. Wu

School of Chemical Engineering and Technology, Tianjin

University, Tianjin, People's Republic of China

X. Han

State Key Laboratory of Hollow Fiber Membrane Materials and Processes, Tianjin Polytechnic University, Tianjin,

People's Republic of China

X. Han

School of Environmental and Chemical Engineering, Tianjin Polytechnic University, Tianjin, People's Republic of China

X. Han $(\bowtie)$

Key Laboratory of Systems Bioengineering,

Ministry of Education, Tianjin University, Tianjin,

People's Republic of China

e-mail: hanxu_mail2013@163.com sulfate concentration increased from 0.2 to $6 \mathrm{~g} \mathrm{~L}^{-1}$, while such an effect was not apparent in As(III) sorption. Nitrate and chloride did not show significant interference on the sorption of both $\mathrm{As}(\mathrm{V})$ and $\mathrm{As}(\mathrm{III})$. Schwertmannite showed better repeated uses in the removal of $\mathrm{As}(\mathrm{V})$ and As(III) after seven repeated using cycles with removal percentages of $95.3 \%$ at $\mathrm{pH} 3.0$ and $63.9 \%$ at $\mathrm{pH} 7.0$ to $\mathrm{As}(\mathrm{V})$, and $31.0 \%$ at $\mathrm{pH} 3.0$ and $81.6 \%$ at $\mathrm{pH} 7.0$ to As(III).

Keywords Arsenite $\cdot$ Arsenate $\cdot$ Iron (hydr)oxide · Schwertmannite $\cdot$ Sorption

\section{Introduction}

Arsenic is a toxic contaminant in aqueous environment, and it is always originated from the weathering of arsenicbearing sulfide minerals such as pyrite and arsenopyrite as well as through a range of anthropogenic activities (Smedley and Kinniburgh 2002; Appleyard et al. 2006). With the extensive use of arsenic-containing fertilizers, fossil fuels and pesticides, arsenic may accumulate in water resources (Mandal and Suzuki 2002). Long-term drinking water with arsenic will cause skin, lung and kidney cancer as well as diseases such as neurological disorders and muscular weakness (Jain and Ali 2000). With the serious toxicity of arsenic, the WHO regulated the discharged guideline of arsenic to $10 \mu \mathrm{g} \mathrm{L}^{-1}$ (WHO 1993). In oxygenrich aqueous environments, arsenate $[\mathrm{As}(\mathrm{V})]$ primarily exists as $\mathrm{H}_{2} \mathrm{AsO}_{4}{ }^{-}$and $\mathrm{HAsO}_{4}{ }^{2-}$ as the $\mathrm{p} K_{\mathrm{a}}$ values of the arsenate acid are $\mathrm{p} K_{\mathrm{a} 1}=2.1, \mathrm{p} K_{\mathrm{a} 2}=6.7$ and $\mathrm{p} K_{\mathrm{a} 3}=11.2$, while arsenite $[\mathrm{As}(\mathrm{III})]$ mainly exists as $\mathrm{H}_{3} \mathrm{AsO}_{3}$ with the $\mathrm{p} K_{\mathrm{a} 1}=9.1, \mathrm{p} K_{\mathrm{a} 2}=12.1$ and $\mathrm{p} K_{\mathrm{a} 3}=13.4$ (Mohan and Pittman 2007). 
Sorption is a promising method for the treatment of arsenic-containing wastewater, and traditional sorbents such as activated carbon, red mud, blast furnace slag, clay minerals, zeolites and some iron oxides are widely used so far. However, activated carbon is expensive and is required in large amounts to purify wastewater, while low-cost sorbents usually show a low sorption capacity and a low selectivity to arsenic. In addition, the treatment of these sorbents after use may also cause secondary pollution to the environment. In the recent years, iron oxides, such as ferrihydrite, magnetite, goethite, hematite and schwertmannite, have been reported to play important roles in the sink of arsenic in natural environments because of their great abundance and high affinities to arsenic (Pedersen et al. 2006). Sorption of arsenic on iron oxides always depends on specific surface areas. Micronsize goethite had a sorption capacity of $12.5 \mathrm{mg} \mathrm{g}^{-1}$ to $\mathrm{As}(\mathrm{V})$ (Ladeira and Ciminelli 2004) and $6.74 \mathrm{mg} \mathrm{g}^{-1}$ to As(III) (Dixit and Hering 2003), while nanoparticles of ferrihydrite and akaganeite had a sorption capacity of 111.02 and $141.3 \mathrm{mg} \mathrm{g}^{-1}$ to $\mathrm{As}(\mathrm{V})$, respectively (Raven et al. 1998; Solozhenkin et al. 2003). Magnetite with the size of $12 \mathrm{~nm}$ had removal percentages of $98.4 \%$ to $\mathrm{As}(\mathrm{V})$ and $99.2 \%$ to $\mathrm{As}(\mathrm{III})$ in the solution of initial arsenic concentrations of $500 \mu \mathrm{g} \mathrm{L}^{-1}$, while the $300 \mathrm{~nm}$ magnetite only showed removal percentages of 29.2 and $24.9 \%$, respectively (Yavuz et al. 2006). Sorption of both $\mathrm{As}(\mathrm{V})$ and $\mathrm{As}(\mathrm{III})$ was significantly affected by $\mathrm{pH}$, with more sorption of $\mathrm{As}(\mathrm{V})$ at lower $\mathrm{pH}$ and more sorption of As(III) at higher $\mathrm{pH}$ (Guo and Chen 2005). Considering the low binding affinity of $\mathrm{As}(\mathrm{III})$ relative to $\mathrm{As}(\mathrm{V})$ with iron oxides (Gupta et al. 2012), oxidation of As(III) to As(V) by oxidants such as $\mathrm{MnO}_{\mathrm{x}}$ and $\mathrm{H}_{2} \mathrm{O}_{2}$ followed by the subsequent sorption of $\mathrm{As}(\mathrm{V})$ on iron oxides seemed to be an effective way for the removal of As(III) (Yamani et al. 2012). Previous studies showed that Fe-Mn binary oxide could have a removal percentage of $89 \%$ to As(III) (Zhang et al. 2007). Guo et al. (2008) also found that $0.5 \mathrm{~mol} \mathrm{~L}^{-1} \mathrm{H}_{2} \mathrm{O}_{2}$ could cause an increase of $15 \%$ in the removal of As(III) by hematite.

Schwertmannite always forms in acidic ( $\mathrm{pH} \mathrm{3-4)}$ ) and sulfate-rich aqueous environment. It is a poorly crystalline $\mathrm{Fe}(\mathrm{III})$-hydroxide typically represented as $\mathrm{Fe}_{8} \mathrm{O}_{8}(\mathrm{OH})_{8-2 x}$ $\left(\mathrm{SO}_{4}\right)_{x},(1 \leq x \leq 1.75)$ (Bigham et al. 1996). Its unit cell always consists of $8 \mathrm{FeO}_{3}(\mathrm{OH})_{3}$ octahedra forming double chains, which are shared over edges and run parallel to the $b$ axis (Regenspurg and Peiffer 2005). Sulfate bounds to schwertmannite into the structure (tunnel sulfate) or adsorbs to the surface with a ratio of 3:1 (Bigham et al. 1990). The sorption mechanism of arsenic on schwertmannite involves ligand exchange with surface-adsorbed or structural $\mathrm{SO}_{4}{ }^{2-}$ (Fukushi et al. 2004). Schwertmannite has shown good sorption capacities to As(III) and As(V). It had sorption capacities of $113.9 \mathrm{mg} \mathrm{g}^{-1}$ to $\mathrm{As}(\mathrm{III})$ at $\mathrm{pH} 7.5$ (Liao et al. 2011), while $20 \mathrm{mg} \mathrm{g}^{-1}$ to As(III) at $\mathrm{pH} 3.0$ (Paikaray et al. 2011). As(V) could reach a sorption capacity of $80.9 \mathrm{mg} \mathrm{g}^{-1}$ on schwertmannite at $\mathrm{pH} 4.0$ (Fukushi et al. 2003b).

Although sorption mechanism of arsenic on schwertmannite was clearly known and the transformation of schwertmannite to the more stable iron oxides was also investigated (Davidson et al. 2008; Collins et al. 2010), the potential of using this environmental-friendly sorbent in the removal of arsenic wastewater is still not discussed. In this study, two synthetic methods will be used in order to obtain schwertmannite with the large specific surface area. Sorption capacities of this iron oxide to $\mathrm{As}(\mathrm{III})$ and $\mathrm{As}(\mathrm{V})$ will then be investigated at different $\mathrm{pHs}$ or in the presence of different co-existing anions. In addition, the stability of schwertmannite and its using cycles in the repeated treatment of arsenic wastewater will also be explored to test its applicability as an effective arsenic sorbent. The present study was conducted in School of Chemical Engineering and Technology, Tianjin University, Tianjin, PR China, and was carried out from December 2011 to June 2012.

\section{Materials and methods}

\section{Chemicals}

All laboratory glassware was repeatedly rinsed with deionized water before use. All reagents were of analytical grade, and all solutions were prepared with deionized water.

\section{Synthesis of schwertmannite}

Two pathways to prepare schwertmannite were developed. In the $\mathrm{Fe}^{2+}$ oxidation method (Regenspurg et al. 2004), $16.45 \mathrm{~g} \mathrm{FeSO}_{4} \cdot 7 \mathrm{H}_{2} \mathrm{O}$ was dissolved in $1 \mathrm{~L}$ deionized water and reacted with $5.3 \mathrm{~mL} 30 \% \mathrm{H}_{2} \mathrm{O}_{2}$. The solution became dark red, and a red-orange material precipitated immediately with the final $\mathrm{pH}$ of 2.5 after $24 \mathrm{~h}$. The solid was then centrifuged, washed three times and freeze-dried before use. The deionized water was also replaced with diluted $\mathrm{H}_{2} \mathrm{SO}_{4}$ solution with the initial $\mathrm{pH}$ of 3.0 , and the speed of adding $\mathrm{H}_{2} \mathrm{O}_{2}$ was changed from pouring $5.3 \mathrm{~mL}$ to dropwise addition at the speed of $1 \mathrm{~mL}$ per minute. In the $\mathrm{Fe}^{3+}$ hydrolyzation method (Kumpulainen et al. 2008), $500 \mathrm{~mL}$ pre-heated deionized water was mixed with $2.6 \mathrm{~g}$ $\mathrm{Fe}_{2}\left(\mathrm{SO}_{4}\right)_{3}$ in a round-bottomed flask with a mechanical stirrer. The flask was placed in a water bath at $85{ }^{\circ} \mathrm{C}$ for $1 \mathrm{~h}$. The solid was then centrifuged, washed three times and freeze-dried before use. 
Sorption kinetics of $\mathrm{As}(\mathrm{V})$ and $\mathrm{As}(\mathrm{III})$

on schwertmannite

Sorption kinetics was designed as described previously (Ren et al. 2012). Schwertmannite $1 \mathrm{~g} \mathrm{~L}^{-1}$ was equilibrated in $0.1 \mathrm{~mol} \mathrm{~L}^{-1}$ of $150 \mathrm{~mL} \mathrm{NaCl}$ solution for $2 \mathrm{~h}$. $\mathrm{NaCl}$ solution was used to provide a stable background of ionic strength (Burton et al. 2009). After that, As(V) or As(III) was added in the system with the initial concentration of $100 \mathrm{mg} \mathrm{L}^{-1} \cdot \mathrm{pH}$ of the suspension was adjusted to 3.0 only by $\mathrm{HCl}$ or $\mathrm{NaOH}$ to avoid the interferences from other anions such as sulfate and nitrate. Samples were then placed on a shaker at $140 \mathrm{rpm}$ and room temperature $\left(25^{\circ} \mathrm{C}\right)$. During the experiments, $1.2 \mathrm{~mL}$ sample was taken out regularly (every half an hour at first and per hour at last) and centrifuged at 12,000 rpm for $5 \mathrm{~min}$. The supernatant was used to determine the concentration of $\mathrm{As}(\mathrm{V})$ or As(III).

Equilibrium sorption of schwertmannite to $\mathrm{As}(\mathrm{V})$ and $\mathrm{As}(\mathrm{III})$

Equilibrium sorption experiments were also designed as mentioned previously (Liao et al. 2011). Series of As(V) or As(III) were added into the equilibrated schwertmannite suspension in $0.1 \mathrm{~mol} \mathrm{~L}^{-1}$ of $30 \mathrm{~mL} \mathrm{NaCl}$ solution with the sorbent concentration of $1 \mathrm{~g} \mathrm{~L}^{-1}$. The $\mathrm{pH}$ was then readjusted to 3.0 or 7.0 , and reaction time was controlled at $300 \mathrm{~min}$ to ensure the sorption equilibrium. The presence of anions such as sulfate, nitrate and chloride on the sorption of $\mathrm{As}(\mathrm{V})$ and $\mathrm{As}(\mathrm{III})$ by schwertmannite was also investigated with the initial concentration of $\mathrm{As}(\mathrm{V})$ or As(III) of $100 \mathrm{mg} \mathrm{L}^{-1}$. In order to investigate the using cycles of this sorbent in the repeated removal of arsenic contaminated water, a semi-continuous sorption was designed. Schwertmannite $5 \mathrm{~g} \mathrm{~L}^{-1}$ was added in $0.1 \mathrm{~mol}$ $\mathrm{L}^{-1}$ of $30 \mathrm{~mL} \mathrm{NaCl}$ solution with $100 \mathrm{mg} \mathrm{L}^{-1} \mathrm{As}(\mathrm{V})$ or $\mathrm{As}(\mathrm{III})$ at $\mathrm{pH} 3.0$ or 7.0. After reaching equilibrium, the samples were centrifuged and the supernatant was used to determine the concentration of $\mathrm{As}(\mathrm{V})$ or $\mathrm{As}(\mathrm{III})$. The precipitate was subsequently dispersed into the freshly prepared arsenic solution again and repeatedly used in the following removal of arsenic. The initial concentrations of $\mathrm{As}(\mathrm{V})$ or $\mathrm{As}(\mathrm{III})$ were also controlled at $100 \mathrm{mg} \mathrm{L}^{-1}$. Samples were then placed on a shaker at $140 \mathrm{rpm}$ and $25{ }^{\circ} \mathrm{C}$. After $300 \mathrm{~min}, 1.2 \mathrm{~mL}$ of sample was taken out and centrifuged at 12,000 rpm for $5 \mathrm{~min}$, and then the supernatant was used to determine the concentration of $\mathrm{As}(\mathrm{V})$ or As(III).

\section{Analytical methods and characterization}

The concentration of $\mathrm{As}(\mathrm{V})$ and $\mathrm{As}(\mathrm{III})$ was determined by the colorimetric method (Dhar et al. 2004). The color reagent was mixed by ascorbic acid (9.74 wt \%), ammonium molybdate (3 wt\%), potassium antimonyl tartrate $(0.56 \mathrm{wt} \%)$ and sulfuric acid $(22.44 \mathrm{wt} \%)$ with the volume ratios of 2:6:1:5. All samples were acidified by $1 \% \mathrm{HCl}$, and then, $5.5 \mathrm{~mL}$ sample was mixed thoroughly with $0.5 \mathrm{~mL}$ color reagent for the determination of $\mathrm{As}(\mathrm{V})$. As to total As determination, $0.5 \mathrm{~mL} 0.1 \mathrm{M} \mathrm{KIO}_{3}$ was added into the sample for $10 \mathrm{~min}$ to completely oxidize As(III) to $\mathrm{As}(\mathrm{V})$. The color reagent was then added to determine total As in the sample. Absorbance was measured at the wavelength of $880 \mathrm{~nm}$. As(III) concentration was obtained by the subtraction of total As and $\mathrm{As}(\mathrm{V})$ concentrations. In our previous study, detection limits for $\mathrm{As}(\mathrm{V})$ and total As were found to be 0.005 and $0.022 \mathrm{mg} \mathrm{L}^{-1}$, respectively (Han et al. 2011).

The molecular formula of schwertmannite could be expressed as $\mathrm{Fe}_{8} \mathrm{O}_{8}(\mathrm{OH})_{8-2 x}\left(\mathrm{SO}_{4}\right)_{x} \quad(1 \leq x \leq 1.75)$ as mentioned above, and " $x$ " could be determined by the ratio of Fe:S (Bigham et al. 1996). Fe was determined by ICPAES (ICP, Varian $715 \mathrm{~s}$ ) and $\mathrm{BaCl}_{2}$ turbidimetrical method was used for $\mathrm{SO}_{4}{ }^{2-}$ determination (Rodier 1975; Wang et al. 2013). Schwertmannite morphology before and after the treatment of arsenic was characterized by a high-resolution analytical transmission electron microscopy (TEM, JEM-2100F, JEOL). Specific surface area of schwertmannite was determined by a volumetric adsorption analyzer (BET, Tristar 3000, Micromeritics). The crystalline structure of schwertmannite was characterized by X-ray diffraction (XRD, D/Max-2500, Rigaku) using an X-ray diffractometer fitted with a $\mathrm{Cu} X$-ray source. Samples were scanned from $2 \theta=10^{\circ}-90^{\circ}$ with a $2 \theta=0.02^{\circ}$ step size.

\section{Results and discussion}

\section{Characterization of synthesized schwertmannite}

The crystalline structures of schwertmannite synthesized through different methods were investigated by XRD (Fig. 1a). Abbreviations of schwertmannite synthesized through various methods were as follows: $\mathrm{Fe}^{2+}$ oxidation method with a low speed of $\mathrm{H}_{2} \mathrm{O}_{2}$ addition in deionized water (Sch-1), $\mathrm{Fe}^{2+}$ oxidation method with a high speed of $\mathrm{H}_{2} \mathrm{O}_{2}$ addition in deionized water ( $\mathrm{Sch}-2), \mathrm{Fe}^{2+}$ oxidation method with a low speed of $\mathrm{H}_{2} \mathrm{O}_{2}$ addition in $\mathrm{H}_{2} \mathrm{SO}_{4}$ solution (Sch-3), $\mathrm{Fe}^{2+}$ oxidation method with a high speed of $\mathrm{H}_{2} \mathrm{O}_{2}$ addition in $\mathrm{H}_{2} \mathrm{SO}_{4}$ solution (Sch-4) and $\mathrm{Fe}^{3+}$ hydrolyzation method (Sch-5). All samples showed the same characteristic peaks at $2 \theta=26^{\circ}, 35^{\circ}$ and $61^{\circ}$, which were the characteristic peaks of schwertmannite (Regenspurg et al. 2004).

XRD results of Sch-1, 2, 3 and 4 showed that changes in $\mathrm{pH}$ and $\mathrm{Fe}^{2+}$ oxidation rate did not cause significant differences in crystalline structure in the $\mathrm{Fe}^{2+}$ oxidation 

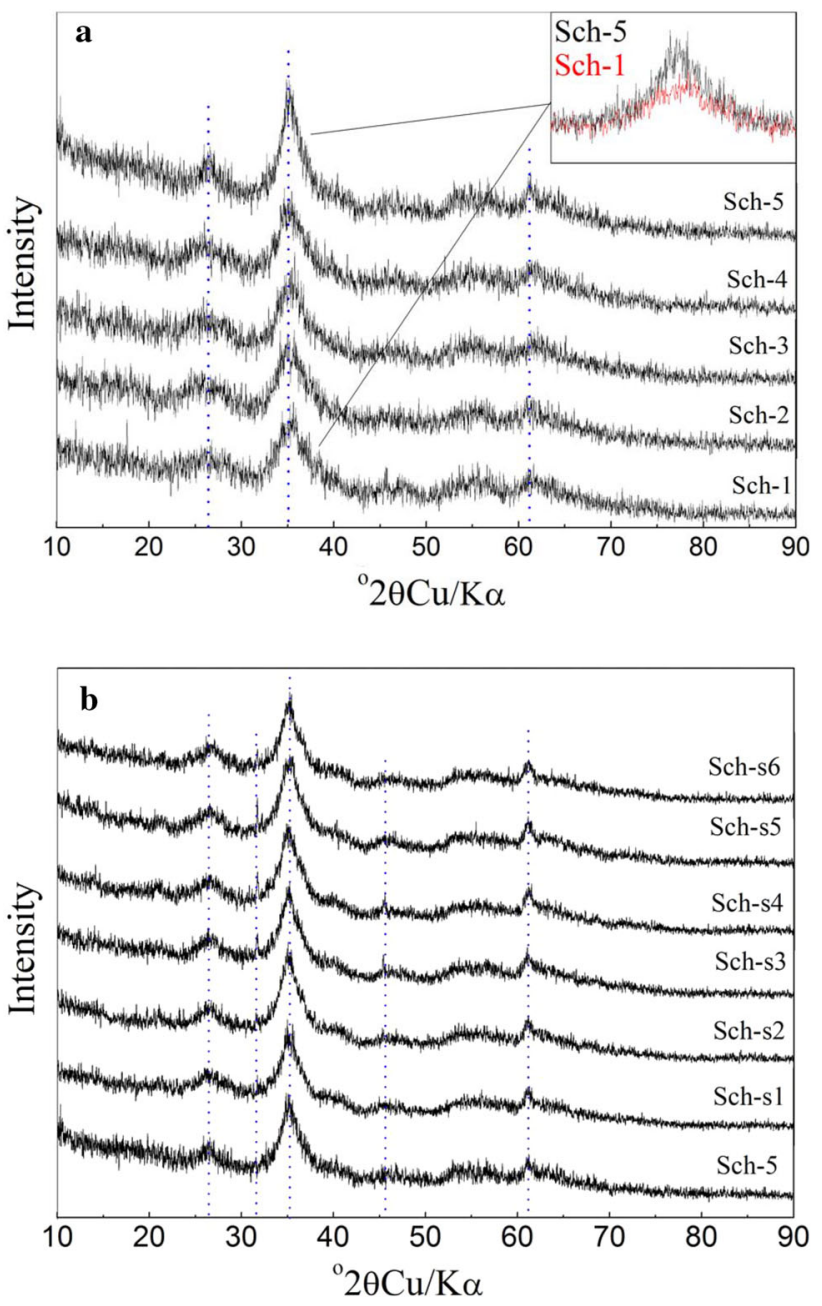

Fig. 1 a XRD analysis of schwertmannite synthesized under different conditions. $\mathrm{Fe}^{2+}$ oxidation method with a low speed of $\mathrm{H}_{2} \mathrm{O}_{2}$ addition in deionized water $(S c h-1), \mathrm{Fe}^{2+}$ oxidation method with a high speed of $\mathrm{H}_{2} \mathrm{O}_{2}$ addition in deionized water (Sch-2), $\mathrm{Fe}^{2+}$ oxidation method with a low speed of $\mathrm{H}_{2} \mathrm{O}_{2}$ addition in $\mathrm{H}_{2} \mathrm{SO}_{4}$ solution (Sch-3), $\mathrm{Fe}^{2+}$ oxidation method with a high speed of $\mathrm{H}_{2} \mathrm{O}_{2}$ addition in $\mathrm{H}_{2} \mathrm{SO}_{4}$ solution $(\mathrm{Sch}-4)$ and $\mathrm{Fe}^{3+}$ hydrolyzation method $(S c h-5)$. b The XRD pattern of schwertmannite after the sorption in the presence of As(III), As(V), sulfate or nitrate. The presence of $100 \mathrm{mg} \mathrm{L}^{-1} \mathrm{As}(\mathrm{V})($ Sch-s 1$), 100 \mathrm{mg} \mathrm{L}^{-1} \mathrm{As}(\mathrm{III})(S c h-s 2), 100 \mathrm{mg}$ $\mathrm{L}^{-1} \mathrm{As}(\mathrm{V})$ and $1,000 \mathrm{mg} \mathrm{L}^{-1} \mathrm{NO}^{3-}$ (Sch-s3), $100 \mathrm{mg} \mathrm{L}^{-1} \mathrm{As}(\mathrm{III})$ and $1,000 \mathrm{mg} \mathrm{L}^{-1} \mathrm{NO}^{3-}$ (Sch-s4), $100 \mathrm{mg} \mathrm{L}^{-1} \mathrm{As}(\mathrm{V})$ and $1,000 \mathrm{mg}$ $\mathrm{L}^{-1} \mathrm{SO}_{4}{ }^{2-}$ (Sch-s5), $100 \mathrm{mg} \mathrm{L}^{-1} \mathrm{As}(\mathrm{III})$ and $1,000 \mathrm{mg} \mathrm{L}^{-1} \mathrm{SO}_{4}{ }^{2-}$ $(S c h-s 6)$ and initial schwertmannite (Sch-5)

method (Fig. 1a). Sch-1 was therefore chosen as a representative schwertmannite and used to make a comparison with Sch-5 in the following characterizations. Compared to Sch-1, 2, 3 and 4, the peaks of Sch-5 were sharper, indicating that Sch-5 had a more orderly crystalline structure.

TEM results showed differences in the morphology and particle size between "Sch-1" and "Sch-5" (Fig. 2). Sch-1 showed a sphere shape with a diameter of $500 \mathrm{~nm}$, while Sch-5 had a hedgehog-like shape with a diameter of
Fig. 2 TEM images in this study. Sch-1 The analysis of schwertmannite synthesized by the $\mathrm{Fe}^{2+}$ oxidation method and Sch-5 schwertmannite synthesized by the $\mathrm{Fe}^{3+}$ hydrolyzation method. Sch-s1, Sch-s2, Sch-s5 and Sch-s6 followed the meanings of symbols in Fig. 1

$100 \mathrm{~nm}$ round core and acicular shell of $100 \mathrm{~nm}$ average lengths. The specific surface area of Sch-1 and Sch-5 was $48.18 \mathrm{~m}^{2} \mathrm{~g}^{-1}$ and $325.52 \mathrm{~m}^{2} \mathrm{~g}^{-1}$, respectively. The specific surface area for schwertmannite was always in the range of $100-300 \mathrm{~m}^{2} \mathrm{~g}^{-1}$ in natural environment (Carlson et al. 2002), while previous studies have suggested the specific surface area of schwertmannite $42.9 \mathrm{~m}^{2} \mathrm{~g}^{-1}$ (Jönsson et al. 2005) and $55 \mathrm{~m}^{2} \mathrm{~g}^{-1}$ (Webster et al. 1998). Considering the larger specific surface area and the better crystalline structure of Sch-5, it was then used to evaluate its sorption performance to $\mathrm{As}(\mathrm{V})$ and $\mathrm{As}(\mathrm{III})$. The different morphology and crystalline structure of schwertmannite between the two synthetic methods might be caused by the growing rate of iron oxides from ions (Tresintsi et al. 2012). In natural environment, schwertmannite showed the hedgehog-like morphology during the gradually growing process (Bigham et al. 1994). Another widely used method for schwertmannite synthesis that lasted for a month also showed similar hedgehog-like morphology (Schwertmann and Cornell 2008). The rapid oxidation and hydrolyzation process of $\mathrm{Fe}$ (II) by $\mathrm{H}_{2} \mathrm{O}_{2}$ in the $\mathrm{Fe}^{2+}$ oxidation method caused the aggregation of the freshly formed schwertmannite units and resulted in a sphere shape with a larger diameter than that of the hedgehog-like schwertmannite (Fernandez-Martinez et al. 2010).

The molecular formula of schwertmannite was commonly accepted as $\mathrm{Fe}_{8} \mathrm{O}_{8}(\mathrm{OH})_{8-2 x}\left(\mathrm{SO}_{4}\right)_{x}(1 \leq x \leq 1.75)$ (Bigham et al., 1996). In our study, the molecular formula of Sch-1 and Sch-5 was $\mathrm{Fe}_{8} \mathrm{O}_{8}(\mathrm{OH})_{4.16}\left(\mathrm{SO}_{4}\right)_{1.92}$ and $\mathrm{Fe}_{8} \mathrm{O}_{8}(\mathrm{OH})_{4.5}\left(\mathrm{SO}_{4}\right)_{1.75}$, respectively. The synthesized schwertmannite always had the molecular formula of $\mathrm{Fe}_{8} \mathrm{O}_{8}(\mathrm{OH})_{3.90 \pm 0.30}\left(\mathrm{SO}_{4}\right)_{2.05 \pm 0.15}$ by the $\mathrm{Fe}^{2+}$ oxidation method (Burton et al. 2008), while a formula of $\mathrm{Fe}_{8} \mathrm{O}_{8}(\mathrm{OH})_{4.47}\left(\mathrm{SO}_{4}\right)_{1.65}$ by the $\mathrm{Fe}^{3+}$ hydrolyzation method was reported in a previous study (Kumpulainen et al. 2008).

Sorption of $\operatorname{As}(\mathrm{V})$ and $\mathrm{As}(\mathrm{III})$ on schwertmannite

Kinetics of $\mathrm{As}(\mathrm{V})$ and $\mathrm{As}(\mathrm{III})$ sorption on schwertmannite showed that both sorption of $\mathrm{As}(\mathrm{V})$ and $\mathrm{As}(\mathrm{III})$ could reach

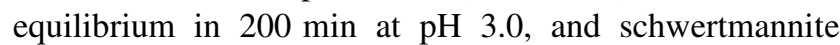
adsorbed more $\mathrm{As}(\mathrm{V}) \quad\left(87.3 \mathrm{mg} \mathrm{g}^{-1}\right)$ than $\mathrm{As}(\mathrm{III})$ (29.6 $\mathrm{mg} \mathrm{g}^{-1}$ ) under the experimental conditions (Fig. 3).

Sorption capacities of $\mathrm{As}(\mathrm{V})$ and $\mathrm{As}(\mathrm{III})$ were also evaluated under different arsenic concentrations and $\mathrm{pH}$ values. Equilibrium isotherm showed that the sorption 

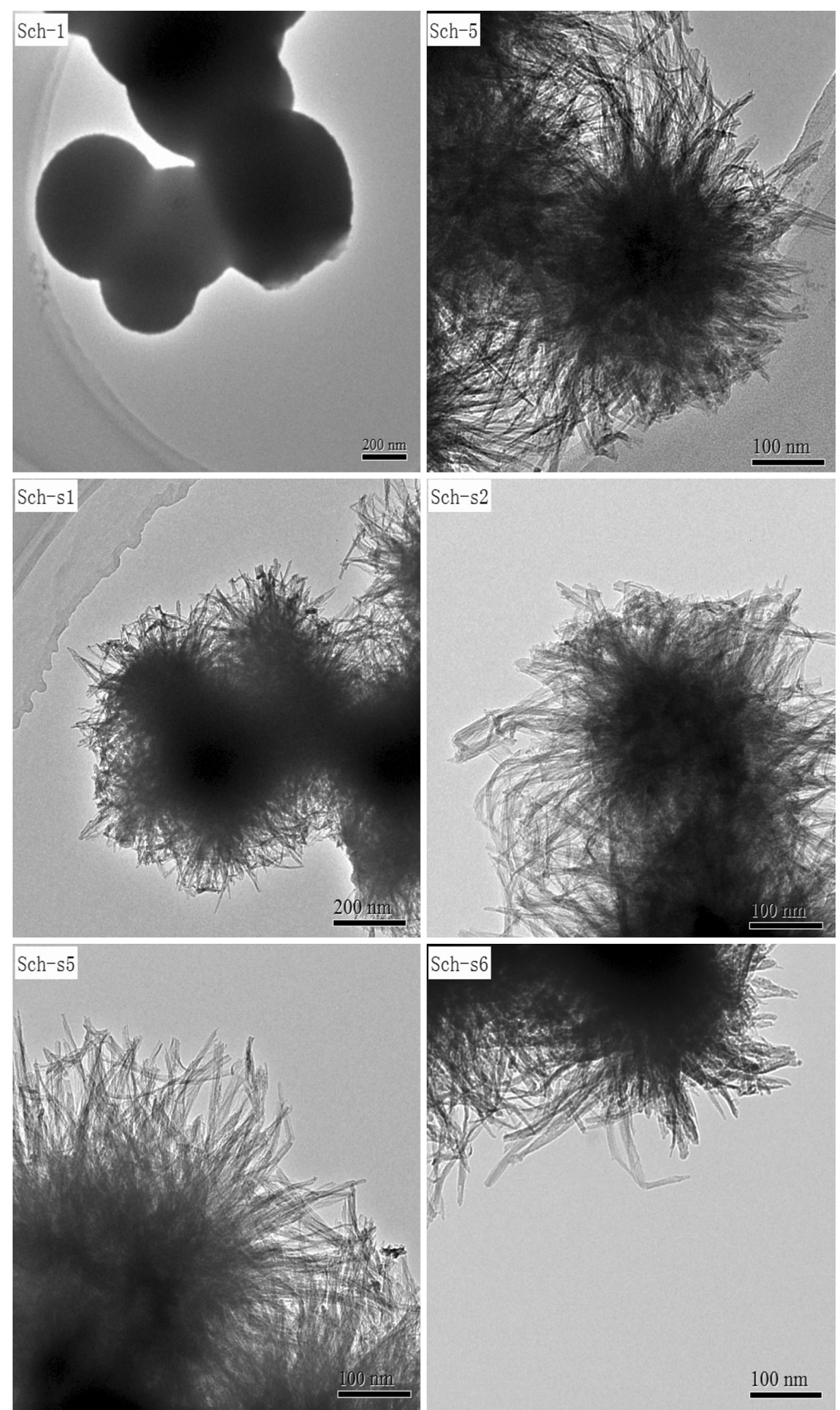


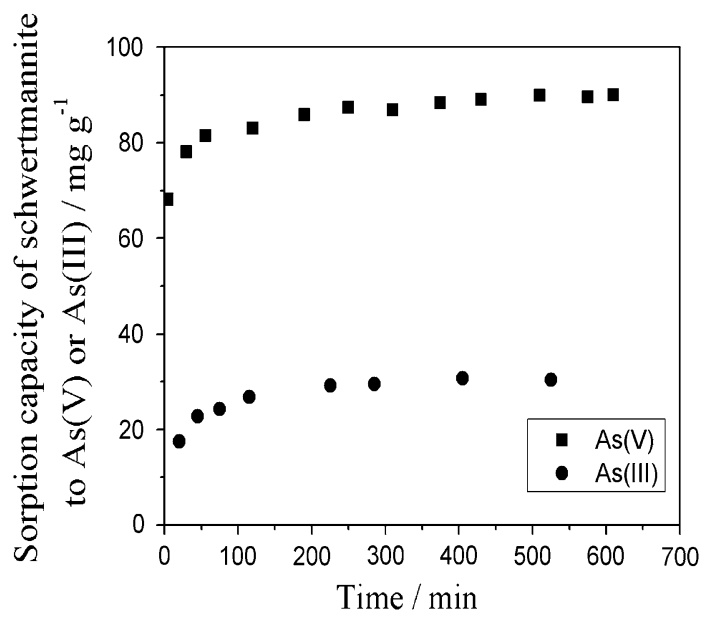

Fig. 3 Sorption kinetics of $\mathrm{As}(\mathrm{V})$ and $\mathrm{As}(\mathrm{III})$ on schwertmannite at $\mathrm{pH} 3.0$ under the conditions of schwertmannite of $1 \mathrm{~g} \mathrm{~L}^{-1}$ and arsenic of $100 \mathrm{mg} \mathrm{L}^{-1}$

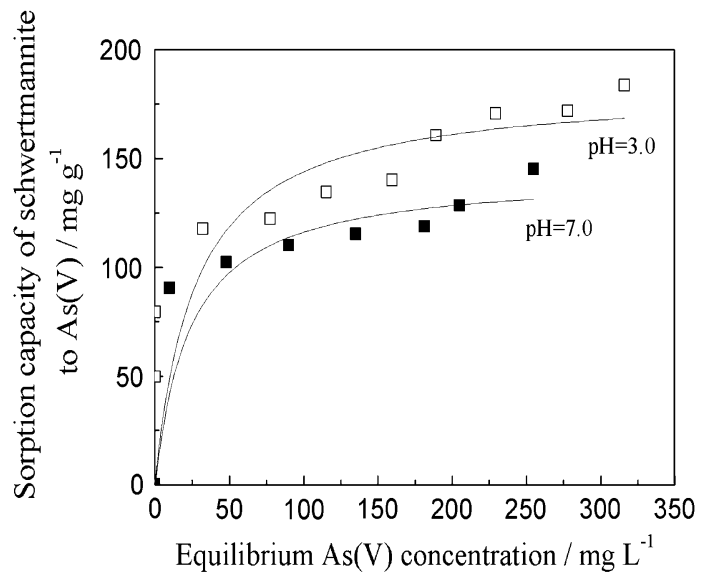

Fig. 4 Sorption capacity of $\mathrm{As}(\mathrm{V})$ on schwertmannite at $\mathrm{pH} 3.0$ and 7.0 with schwertmannite concentration of $1 \mathrm{~g} \mathrm{~L}^{-1}$; the lines represent simulation results by Langmuir isotherm

capacity increased rapidly at low $\mathrm{As}(\mathrm{V})$ and $\mathrm{As}(\mathrm{III})$ concentrations and began to level off at high concentrations, indicating saturation of the sorption sites on schwertmannite. The sorption capacity of $\mathrm{As}(\mathrm{V})$ and $\mathrm{As}(\mathrm{III})$ on schwertmannite could be well described by the Langmuir model. The maximum sorption capacities of $\mathrm{As}(\mathrm{V})$ were 182.86 and $143.25 \mathrm{mg} \mathrm{g}^{-1}$ at $\mathrm{pH} 3.0$ and $\mathrm{pH} 7.0$, respectively, and it was obvious that sorption of $\mathrm{As}(\mathrm{V})$ was more favorable at lower $\mathrm{pH}$ (Fig. 4; Table 1). Sorption of As(III) was contrary to that of $\mathrm{As}(\mathrm{V})$, and more $\mathrm{As}(\mathrm{III})$ could be removed under higher $\mathrm{pH}$, with 45.50 and $217.85 \mathrm{mg} \mathrm{g}^{-1}$ to $\mathrm{As}(\mathrm{III})$ at $\mathrm{pH} 3.0$ and $\mathrm{pH}$ 7.0, respectively (Fig. 5; Table 1). This suggested that schwertmannite had a larger sorption capacity than the conventional sorbents. Activated carbon sorbents showed arsenic sorption capacities of $29.9 \mathrm{mg} \mathrm{g}^{-1}$ to $\mathrm{As}(\mathrm{III})$ and $30.48 \mathrm{mg} \mathrm{g}^{-1}$ to
Table 1 Sorption capacity of schwertmannite to $\mathrm{As}(\mathrm{V})$ or $\mathrm{As}(\mathrm{III})$ under $\mathrm{pH} 3$ and 7

\begin{tabular}{llll}
\hline As species & $Q_{\max }\left(\mathrm{mg} \mathrm{g}^{-1}\right)$ & $K$ & $R^{2}$ \\
\hline As(V), pH 3 & 182.86 & 0.037 & 0.940 \\
As(V), pH 7 & 143.25 & 0.043 & 0.968 \\
As(III), pH 3 & 45.50 & 0.034 & 0.984 \\
As(III), pH 7 & 217.85 & 0.025 & 0.964 \\
\hline
\end{tabular}

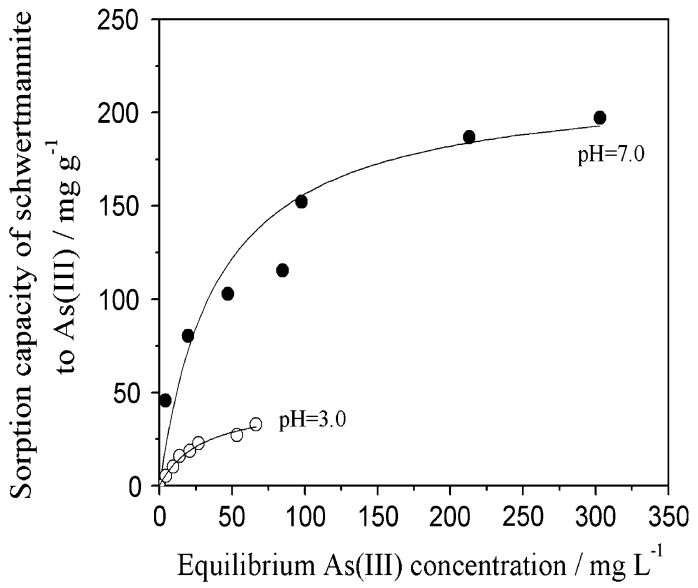

Fig. 5 Sorption capacity of As(III) on schwertmannite at pH 3.0 and 7.0 with schwertmannite concentration of $1 \mathrm{~g} \mathrm{~L}^{-1}$; the lines represent simulation results by Langmuir isotherm

As(V) (Pattanayak et al. 2000). Goethite, ferrihydrite and akaganeite showed sorption capacities of 12.5, 111.02 and $141.3 \mathrm{mg} \mathrm{g}^{-1}$ to $\mathrm{As}(\mathrm{V})$, respectively, which were all less than that of schwertmannite (Raven et al. 1998; Solozhenkin et al. 2003; Ladeira and Ciminelli 2004). The higher sorption capacity of schwertmannite than that of the conventional sorbents and other iron oxides suggested that schwertmannite could be used as an efficient sorbent for the removal of $\mathrm{As}(\mathrm{V})$ and $\mathrm{As}(\mathrm{III})$.

In order to further determine the effect of $\mathrm{pH}$ on the removal of arsenic, $\mathrm{pH}$ range from 2.0 to 11.0 was selected in the sorption process. Figure 6 further confirmed that lower $\mathrm{pH}$ was in favor of $\mathrm{As}(\mathrm{V})$ sorption, while more As(III) was adsorbed on schwertmannite at higher $\mathrm{pH}$. Schwertmannite had a stable sorption capacity of $\mathrm{As}(\mathrm{V}) 87.3 \mathrm{mg} \mathrm{g}^{-1}$ from $\mathrm{pH} 3.0$ to 7.0 , while it decreased significantly from $\mathrm{pH} 7.0$ to 11.0 with a result of $\mathrm{As}(\mathrm{V}) 73.0 \mathrm{mg} \mathrm{g}^{-1}$ at $\mathrm{pH}$ 11.0. Sorption of As(III) was different from $\mathrm{As}(\mathrm{V})$, which increased with the increase in $\mathrm{pH}$. The sorption capacity of As(III) increased from $7.4 \mathrm{mg} \mathrm{g}^{-1}$ at $\mathrm{pH} 2.0$ to $88.0 \mathrm{mg} \mathrm{g}^{-1}$ at $\mathrm{pH} 11.0$.

The effect of $\mathrm{pH}$ on the sorption of arsenic on schwertmannite could be attributed to the speciation of arsenic, the surface charge of schwertmannite in aquatic environment and the sorption mechanism. $\mathrm{As}(\mathrm{V})$ exists as $\mathrm{H}_{3} \mathrm{AsO}_{4}$ 


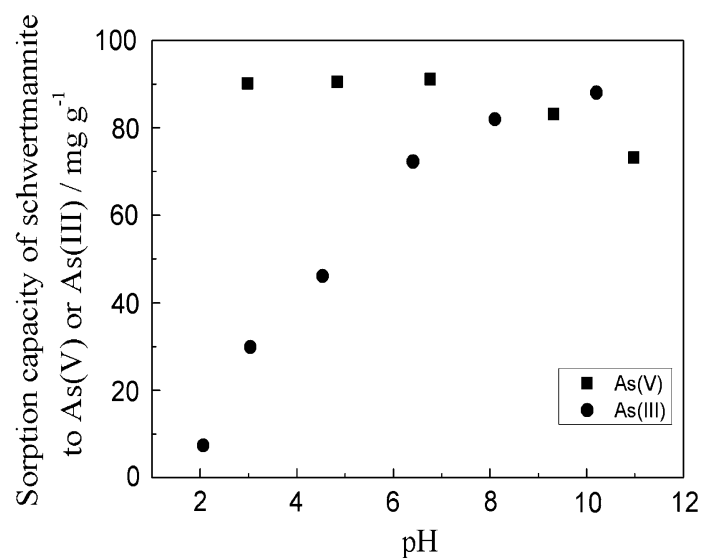

Fig. 6 Effect of $\mathrm{pH}$ on the sorption of $\mathrm{As}(\mathrm{V})$ and $\mathrm{As}(\mathrm{III})$ on schwertmannite under the conditions of schwertmannite of $1 \mathrm{~g} \mathrm{~L}^{-1}$ and arsenic of $100 \mathrm{mg} \mathrm{L}^{-1}$

and $\mathrm{H}_{2} \mathrm{AsO}_{4}{ }^{-}$at $\mathrm{pH}<3$; as $\mathrm{H}_{2} \mathrm{AsO}_{4}{ }^{-}$at $4<\mathrm{pH}<5.5$; and as $\mathrm{HAsO}_{4}{ }^{2-}$ and $\mathrm{AsO}_{4}{ }^{3-}$ when $\mathrm{pH}>7$ (Fig. 7). It could be deduced that the positively charged schwertmannite [the point of zero charge $\left(\mathrm{pH}_{\mathrm{pzc}}\right)$ of schwertmannite was 7.2 (Jönsson et al. 2005)] could easily adsorb $\mathrm{H}_{2} \mathrm{AsO}_{4}{ }^{-}$at low $\mathrm{pH}$, while having a low sorption capacity of $\mathrm{HAsO}_{4}{ }^{2-}$ and $\mathrm{AsO}_{4}{ }^{3-}$ at high $\mathrm{pH}$. The effect of $\mathrm{pH}$ on the sorption of $\mathrm{As}(\mathrm{V})$ to goethite, hematite and magnetite also showed similar tendency with steady sorption capacity under acid condition and significant decrease under alkalic condition (Mamindy-Pajany et al. 2011).

The sorption behavior of As(III) was inverse to that of $\mathrm{As}(\mathrm{V})$. As(III) primarily exists as $\mathrm{H}_{3} \mathrm{AsO}_{3}$ when $\mathrm{pH}<7$ and exists as $\mathrm{H}_{3} \mathrm{AsO}_{3}$ and $\mathrm{H}_{2} \mathrm{AsO}_{3}{ }^{-}$when $\mathrm{pH}>7$. The abundant positive charge on schwertmannite under acidic condition had little effect on the sorption of the neutral $\mathrm{H}_{3} \mathrm{AsO}_{3}$. In addition to electronic attraction, ligand exchange also played important roles in the sorption of As(III) on schwertmannite. Sulfate adsorbed or incorporated into the structure of schwertmannite could exchange with arsenate and arsenite in solution (Fukushi et al. 2004; Liao et al. 2011). As the proton could stabilize the sulfate in schwertmannite (Burton et al. 2009), the high $\mathrm{pH}$ favored the ligand exchange between arsenite and sulfate. That was the reason why sorption of $\mathrm{H}_{3} \mathrm{AsO}_{3}$ increased with the increase of $\mathrm{pH}$. Kersten and Vlasova (2009) also found that sorption capacity of As(III) on goethite increased with $\mathrm{pH}$ and reached the maximum value at $\mathrm{pH}$ 9.0, followed by a decrease when $\mathrm{pH}>9$.

The effect of ligand exchange also contributed to the sorption of $\mathrm{As}(\mathrm{V})$ at high $\mathrm{pH}$. With the decrease in positive charges on schwertmannite as $\mathrm{pH}$ increased from 3.0 to 6.8, no significant difference was found in the sorption capacities of $\mathrm{As}(\mathrm{V})$. It could be attributed to the increase in the ligand exchange between $\mathrm{As}(\mathrm{V})$ and sulfate at high $\mathrm{pH}$. Although further increase of $\mathrm{pH}$ (from 6.8 to 11.0) could increase the ligand exchange between $\mathrm{As}(\mathrm{V})$ and sulfate, sorption of $A s(V)$ decreased due to the electronic repulsion between negative charges on schwertmannite and $\mathrm{HAsO}_{4}{ }^{2-} / \mathrm{AsO}_{4}{ }^{3-}$ under alkalic conditions.

The presence of sulfate significantly decreased the sorption capacity of $\mathrm{As}(\mathrm{V})$ with a decrease of $19.5 \mathrm{mg} \mathrm{g}^{-1}$ from sulfate concentration of $0.2-6 \mathrm{~g} \mathrm{~L}^{-1}$, while such an effect was not significant in As(III) sorption process. Nitrate and chloride did not show significant interference on the sorption of $\mathrm{As}(\mathrm{V})$ or $\mathrm{As}(\mathrm{III})$ on schwertmannite (Fig. 8). Previous studies showed that sulfate could cause a decrease of $5 \%$ in $\mathrm{As}(\mathrm{V})$ sorption on hematite (Youngran et al. 2007). Chloride could cause $\mathrm{As}(\mathrm{V})$ sorption decrease in 24,10 and $8 \%$ on magnetite, hematite, and goethite, respectively (Mamindy-Pajany et al. 2011). These coexisting anions did not have significant effects on the
Fig. 7 Speciation of $\mathrm{As}(\mathrm{V})$ and As(III) under different $\mathrm{pH}$ conditions (Smedley and Kinniburgh 2002)
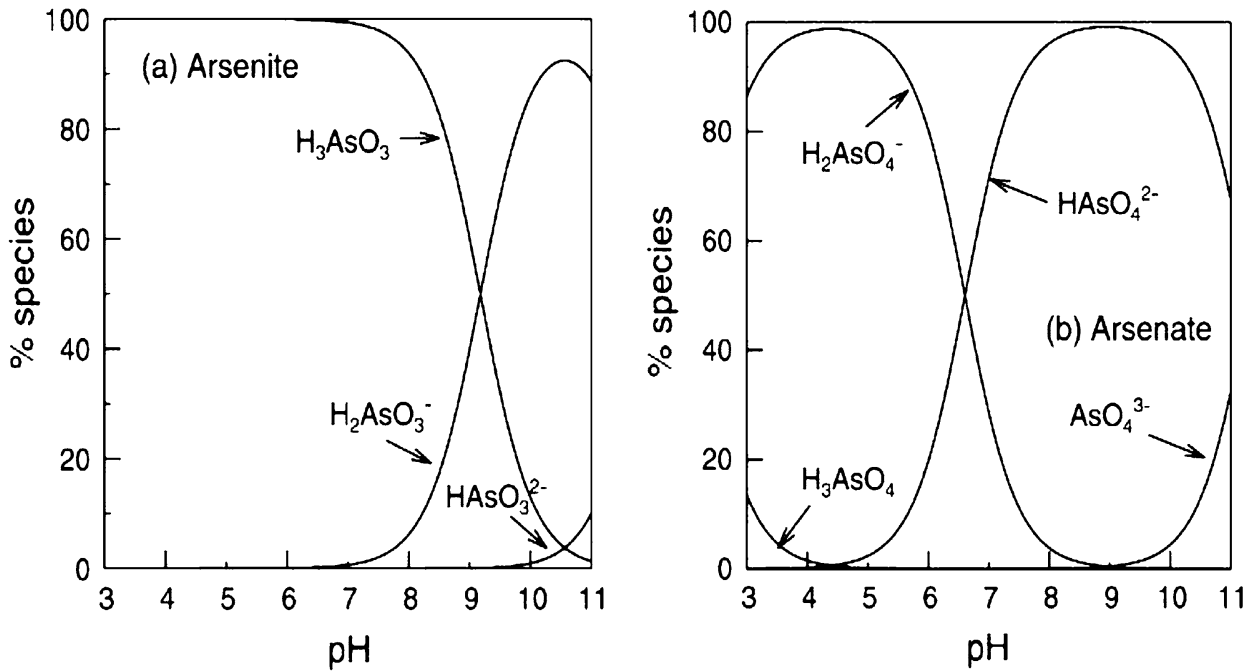
Fig. 8 Effect of co-existing anions on the sorption of $\mathrm{As}(\mathrm{V})$ and $\mathrm{As}(\mathrm{III})$ on schwertmannite at $\mathrm{pH} 3.0$ under the conditions of

schwertmannite of $1 \mathrm{~g} \mathrm{~L}^{-1}$ and As of $100 \mathrm{mg} \mathrm{L}^{-1}$. a, $\mathbf{b}$ and c The effects of $\mathrm{SO}_{4}{ }^{2-}, \mathrm{NO}^{3-}$, and $\mathrm{Cl}^{-}$, respectively a

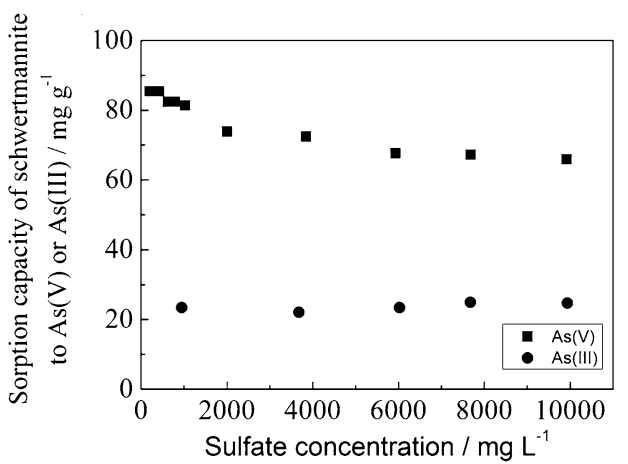

c

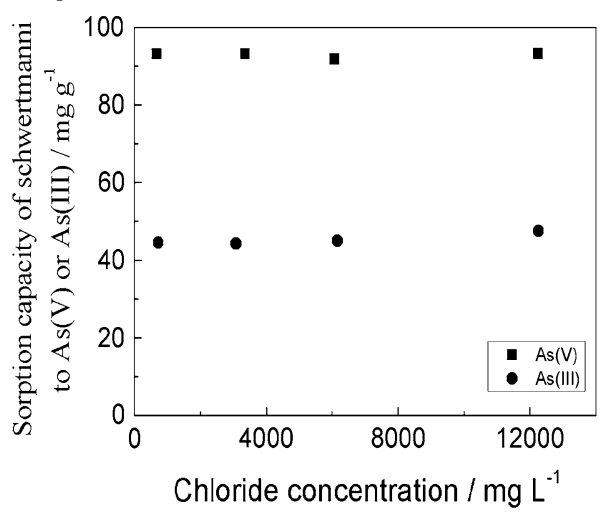

b

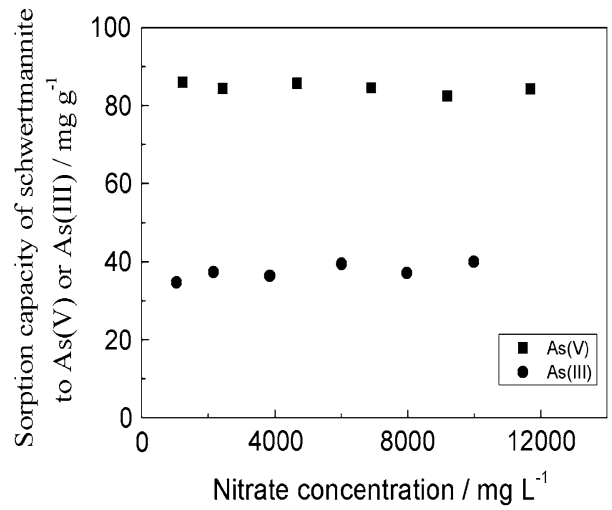

sorption capacities to $\mathrm{As}(\mathrm{V})$ and $\mathrm{As}(\mathrm{III})$, and schwertmannite synthesized in our study might be used in arsenicpolluted wastewater with high ionic strength.

Characterization of schwertmannite after sorption of $\mathrm{As}(\mathrm{V})$ or $\mathrm{As}(\mathrm{III})$

The structure and morphology of schwertmannite after $\mathrm{As}(\mathrm{V})$ or $\mathrm{As}(\mathrm{III})$ sorption with co-existing anions were investigated by XRD and TEM. In the presence of $100 \mathrm{mg}$ $\mathrm{L}^{-1} \mathrm{As}(\mathrm{V})$ (Sch-s1); $100 \mathrm{mg} \mathrm{L}^{-1} \mathrm{As}$ (III) (Sch-s2); $100 \mathrm{mg}$ $\mathrm{L}^{-1} \mathrm{As}(\mathrm{V})$ and $1,000 \mathrm{mg} \mathrm{L}^{-1} \mathrm{NO}^{3-}$ (Sch-s3); $100 \mathrm{mg} \mathrm{L}^{-1}$ As(III) and $1,000 \mathrm{mg} \mathrm{L}^{-1} \mathrm{NO}^{3-}$ (Sch-s4); $100 \mathrm{mg} \mathrm{L}^{-1}$ As(V) and 1,000 $\mathrm{mg} \mathrm{L}^{-1} \mathrm{SO}_{4}{ }^{2-}$ (Sch-s5); and $100 \mathrm{mg} \mathrm{L}^{-1}$ As(III) and $1,000 \mathrm{mg} \mathrm{L}^{-1} \mathrm{SO}_{4}{ }^{2-}$ (Sch-s6), XRD analysis indicated that no significant change was found in schwertmannite crystalline structure, and TEM images also showed no morphological change in schwertmannite (Fig. 1b, 2 Sch-s1, Sch-s2, Sch-s5 and Sch-s6). The little peaks appeared at $2 \theta=32^{\circ}$ and $45^{\circ}$ were the peaks of background $\mathrm{NaCl}$ in the sorption system. From the contrast of schwertmannite in the presence of different anions (Schs1 to Sch-s6) with the initial schwertmannite (Sch-5), differences could be found at positions of $2 \theta=27^{\circ}, 35^{\circ}$ and $62^{\circ}$ (Fig. 1b). The three sharper peaks of Sch-s1 to Sch-s6 indicated that $\mathrm{As}(\mathrm{V})$ and $\mathrm{As}(\mathrm{III})$ could improve the regularity and ordering of schwertmannite (Fukushi et al. 2003a). Schwertmannite is a metastable mineral and previous studies showed that arsenic could retard the slow transformation of schwertmannite to goethite under oxidizing conditions (Acero et al. 2006; Burton et al. 2010). However, $99 \%$ of the adsorbed arsenic remained in the solid phase throughout the entire aging and transform process (Acero et al. 2006), which suggested the possibility of applying this kind of iron hydroxide as a stable sorbent for the removal of arsenic in wastewater with no secondary pollution even it was transformed to other iron oxides.

Aftertreatment of the arsenic-adsorbed schwertmannite

Results from repeated use of schwertmannite in arsenic removal showed that schwertmannite could adsorb arsenic sufficiently at specific $\mathrm{pH}$ condition (Fig. 9). The results showed that $5 \mathrm{~g} \mathrm{~L} \mathrm{~L}^{-1}$ schwertmannite could adsorb $120 \mathrm{mg} \mathrm{g}^{-1} \mathrm{As}(\mathrm{V})$ with no arsenic left in the solution at $\mathrm{pH} 3.0$ during the six-cycles sorption and $99.32 \mathrm{mg} \mathrm{g}^{-1}$ $\mathrm{As}(\mathrm{III})$ at $\mathrm{pH} 7.0$ in the five-cycles sorption. Sorption of As(V) decreased $4.7 \%$ in the seventh cycle at $\mathrm{pH} 3.0$, while 7.3 and $36.2 \%$ decrease in the sixth and seventh cycles at pH 7.0, respectively. Sorption of As(III) showed a more stable sorption property at $\mathrm{pH} 7.0$ than $\mathrm{As}(\mathrm{V})$, which decreased $3.4,4.5$ and $18.4 \%$ in the fifth to seventh cycles, 


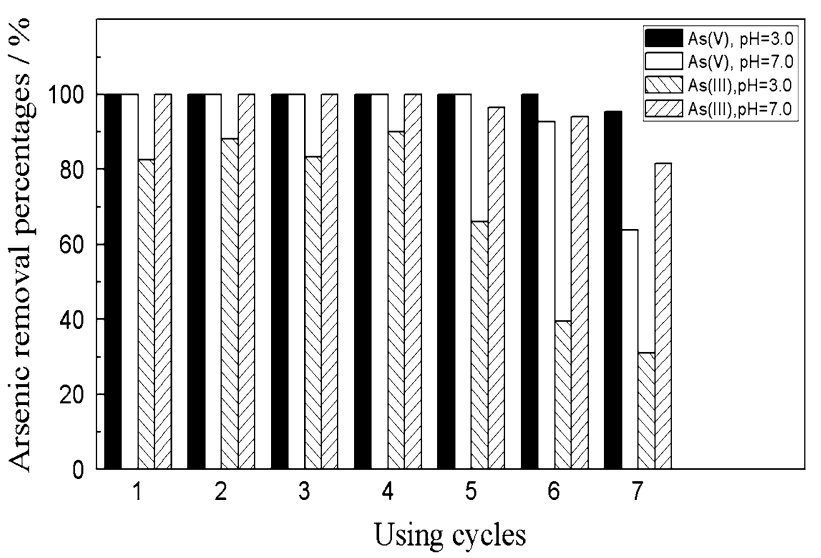

Fig. 9 Continuous sorption of $\mathrm{As}(\mathrm{V})$ and $\mathrm{As}(\mathrm{III})$ on schwertmannite at $\mathrm{pH} 3.0$ and $\mathrm{pH} 7.0$ with schwertmannite concentration of $5 \mathrm{~g} \mathrm{~L}^{-1}$ and As concentration of $100 \mathrm{mg} \mathrm{L}^{-1}$ in each using cycle

respectively. Although the sorption of $\mathrm{As}(\mathrm{III})$ at $\mathrm{pH} 3.0$ was lower than 7.0, it could still keep a stable sorption capacity during the four-cycles sorption which showed a good using cycles property. The results indicated that schwertmannite could be a reusable sorbent.

How to treat the sorbents after losing sorption capacity to contaminants is a big problem in the scale-up of sorption process. Considering the easy dissolution of the arsenicloaded schwertmannite by acids, it was reasonable to use this kind of environmental-friendly sorbent to concentrate diluted-arsenic from arsenic-containment water. Schwertmannite after seven-cycles' use in this study was dissolved in $25 \mathrm{~mL} 65 \% \mathrm{HNO}_{3}$, and the concentration of arsenic in the solution reached $\mathrm{As}(\mathrm{V})$ of $720 \mathrm{mg} \mathrm{L}^{-1}$ or $\mathrm{As}(\mathrm{III})$ of $596 \mathrm{mg} \mathrm{L}^{-1}$. In this case, both $\mathrm{Fe}(\mathrm{III})$ and concentrated arsenic could be effectively recovered for further purification with no secondary pollution produced.

\section{Conclusion}

In this study, we developed a high-surface-area schwertmannite which showed higher sorption capacities to $\mathrm{As}(\mathrm{V})$ and $\mathrm{As}(\mathrm{III})$ than that of most of adsorbents in previous studies. Besides, the adsorption of arsenic could stabilize the structure of schwertmannite, which was a significant difference with common adsorbents that could avoid the release of the adsorbed arsenic. The present study revealed that schwertmannite synthesized from $\mathrm{Fe}^{3+}$ hydrolyzation method had a large specific surface area of $325.5 \mathrm{~m}^{2} \mathrm{~g}^{-1}$ and showed a maximum sorption capacity to $\mathrm{As}(\mathrm{V})$ of $182.86 \mathrm{mg} \mathrm{g}^{-1}$ at $\mathrm{pH} 3.0$ and $\mathrm{As}(\mathrm{III})$ of $217.85 \mathrm{mg} \mathrm{g}^{-1}$ at $\mathrm{pH}$ 7.0. The $\mathrm{pH}$-dependent sorption of $\mathrm{As}(\mathrm{V})$ remained stable with a capacity of $87.3 \mathrm{mg} \mathrm{g}^{-1}$ from $\mathrm{pH} 3.0$ to 7.0 and decreased significantly from $\mathrm{pH} 7.0$ to 11.0 , with a result of $73.0 \mathrm{mg} \mathrm{g}^{-1}$ at $\mathrm{pH} 11.0$. The sorption behavior of As(III) was contrary to that of As(V), which increased with the increase of $\mathrm{pH}$ with sorption capacities of 7.4 and $88.0 \mathrm{mg} \mathrm{g}^{-1}$ at $\mathrm{pH} 2.0$ and 11.0 , respectively. Co-existing sulfate could decrease the sorption of $\mathrm{As}(\mathrm{V})$ but not $\mathrm{As}(\mathrm{III})$, while no obvious effects were detected for $\mathrm{As}(\mathrm{V})$ and $\mathrm{As}(\mathrm{III})$ sorption by nitrate and chloride. XRD and TEM analyses also showed no significant change on the crystalline structure or morphology of schwertmannite after the sorption of $\mathrm{As}(\mathrm{V})$ and $\mathrm{As}(\mathrm{III})$. Schwertmannite showed a better performance in the repeated removal of $\mathrm{As}(\mathrm{V})$ than that of $\mathrm{As}(\mathrm{III})$. The dilutedarsenic-contaminated wastewater could be effectively recovered by dissolving the arsenic-containing iron oxides by acids, which indicated that schwertmannite could be used as a stable, reusable and environmental-friendly sorbent in the removal of $\mathrm{As}(\mathrm{V})$ and $\mathrm{As}(\mathrm{III})$.

Acknowledgments We greatlfully acknowledge the financial support from the National Natural Science Foundation of China (X.H., No.41003040 and No.41373114; Y.L., No.41201487) and the Open Funding Project of the Key Laboratory of Systems Bioengineering, Ministry of Education (X.H.). We are also grateful for the Program of Introducing Talents of Discipline to Universities (S.-Y.J., No.B06006).

\section{References}

Acero P, Ayora C, Torrentó C, Nieto JM (2006) The behavior of trace elements during schwertmannite precipitation and subsequent transformation into goethite and jarosite. Geochim Cosmochim Acta 70(16):4130-4139

Appleyard SJ, Angeloni J, Watkins R (2006) Arsenic-rich groundwater in an urban area experiencing drought and increasing population density, Perth, Australia. Appl Geochem 21(1):83-97

Bigham JM, Schwertmann U, Carlson L, Murad E (1990) A poorly crystallized oxyhydroxysulfate of iron formed by bacterial oxidation of $\mathrm{Fe}(\mathrm{II})$ in acid mine waters. Geochim Cosmochim Acta 54(10):2743-2758

Bigham JM, Carlson L, Murad E (1994) Schwertmannite, a new iron oxyhydroxysulphate from Pyhasalmi, Finland, and other localities. Mineral Mag 58(393):641-648

Bigham JM, Schwertmann U, Traina SJ, Winland RL, Wolf M (1996) Schwertmannite and the chemical modeling of iron in acid sulfate waters. Geochim Cosmochim Acta 60(12):2111-2121

Burton ED, Bush RT, Sullivan LA, Mitchell DRG (2008) Schwertmannite transformation to goethite via the $\mathrm{Fe}(\mathrm{II})$ pathway: reaction rates and implications for iron-sulfide formation. Geochim Cosmochim Acta 72(18):4551-4564

Burton ED, Bush RT, Johnston SG, Watling KM, Hocking RK, Sullivan LA, Parker GK (2009) Sorption of Arsenic(V) and Arsenic(III) to schwertmannite. Environ Sci Technol 43(24):9202-9207

Burton ED, Johnston SG, Watling K, Bush RT, Keene AF, Sullivan LA (2010) Arsenic effects and behavior in association with the $\mathrm{Fe}$ (II)-catalyzed transformation of schwertmannite. Environ Sci Technol 44(6):2016-2021

Carlson L, Bigham JM, Schwertmann U, Kyek A, Wagner F (2002) Scavenging of As from acid mine drainage by schwertmannite and ferrihydrite: a comparison with synthetic analogues. Environ Sci Technol 36(8):1712-1719 
Collins RN, Jones AM, Waite TD (2010) Schwertmannite stability in acidified coastal environments. Geochim Cosmochim Acta 74(2):482-496

Davidson LE, Shaw S, Benning LG (2008) The kinetics and mechanisms of schwertmannite transformation to goethite and hematite under alkaline conditions. Am Mineral 93(8-9): $1326-1337$

Dhar RK, Zheng Y, Rubenstone J, van Geen A (2004) A rapid colorimetric method for measuring arsenic concentrations in groundwater. Anal Chim Acta 526(2):203-209

Dixit S, Hering JG (2003) Comparison of arsenic(V) and arsenic(III) sorption onto iron oxide minerals: implications for arsenic mobility. Environ Sci Technol 37(18):4182-4189

Fernandez-Martinez A, Timon V, Roman-Ross G, Cuello GJ, Daniels JE, Ayora C (2010) The structure of schwertmannite, a nanocrystalline iron oxyhydroxysulfate. Am Mineral 95(8-9): $1312-1322$

Fukushi K, Sasaki M, Sato T, Yanase N, Amano H, Ikeda H (2003a) A natural attenuation of arsenic in drainage from an abandoned arsenic mine dump. Appl Geochem 18(8):1267-1278

Fukushi K, Sato T, Yanase N (2003b) Solid-solution reactions in As(V) sorption by schwertmannite. Environ Sci Technol 37(16):3581-3586

Fukushi K, Sato T, Yanase N, Minato J, Yamada H (2004) Arsenate sorption on schwertmannite. Am Mineral 89(11-12):1728-1734

Guo X, Chen F (2005) Removal of arsenic by bead cellulose loaded with iron oxyhydroxide from groundwater. Environ Sci Technol 39(17):6808-6818

Guo H, Stüben D, Berner Z, Kramar U (2008) Adsorption of arsenic species from water using activated siderite-hematite column filters. J Hazard Mater 151(2-3):628-635

Gupta K, Bhattacharya S, Nandi D, Dhar A, Maity A, Mukhopadhyay A, Chattopadhyay DJ, Ray NR, Sen P, Ghosh UC (2012) Arsenic(III) sorption on nanostructured cerium incorporated manganese oxide (NCMO): a physical insight into the mechanistic pathway. J Colloid Interf Sci 377(1):269-276

Han X, Li YL, Gu JD (2011) Oxidation of As(III) by $\mathrm{MnO}_{2}$ in the absence and presence of $\mathrm{Fe}(\mathrm{II})$ under acidic conditions. Geochim Cosmochim Acta 75(2):368-379

Jain CK, Ali I (2000) Arsenic: occurrence, toxicity and speciation techniques. Water Res 34(17):4304-4312

Jönsson J, Persson P, Sjöberg S, Lövgren L (2005) Schwertmannite precipitated from acid mine drainage: phase transformation, sulphate release and surface properties. Appl Geochem 20(1):179-191

Kersten M, Vlasova N (2009) Arsenite adsorption on goethite at elevated temperatures. Appl Geochem 24(1):32-43

Kumpulainen S, Räisänen ML, von der Kammer F, Hofmann T (2008) Ageing of synthetic and natural schwertmannites at $\mathrm{pH}$ 2-8. Clay Miner 43(3):437-448

Ladeira AC, Ciminelli VS (2004) Adsorption and desorption of arsenic on an oxisol and its constituents. Water Res 38(8):2087-2094

Liao Y, Liang J, Zhou L (2011) Adsorptive removal of As(III) by biogenic schwertmannite from simulated As-contaminated groundwater. Chemosphere 83(3):295-301

Mamindy-Pajany Y, Hurel C, Marmier N, Roméo M (2011) Arsenic (V) adsorption from aqueous solution onto goethite, hematite, magnetite and zero-valent iron: effects of $\mathrm{pH}$, concentration and reversibility. Desalination 281:93-99
Mandal BK, Suzuki KT (2002) Arsenic round the world: a review. Talanta 58(1):201-235

Mohan D, Pittman CU (2007) Arsenic removal from water/wastewater using adsorbents-a critical review. J Hazard Mater 142(1-2):1-53

Paikaray S, Göttlicher J, Peiffer S (2011) Removal of As(III) from acidic waters using schwertmannite: surface speciation and effect of synthesis pathway. Chem Geol 283(3-4):134-142

Pattanayak J, Mondal K, Mathew S, Lalvani SB (2000) A parametric evaluation of the removal of $\mathrm{As}(\mathrm{V})$ and $\mathrm{As}(\mathrm{III})$ by carbon-based adsorbents. Carbon 38(4):589-596

Pedersen HD, Postma D, Jakobsen R (2006) Release of arsenic associated with the reduction and transformation of iron oxides. Geochim Cosmochim Acta 70(16):4116-4129

Raven KP, Jain A, Loeppert RH (1998) Arsenite and arsenate adsorption on ferrihydrite: kinetics, equilibrium, and adsorption envelopes. Environ Sci Technol 32(3):344-349

Regenspurg S, Peiffer S (2005) Arsenate and chromate incorporation in schwertmannite. Appl Geochem 20(6):1226-1239

Regenspurg S, Brand A, Peiffer S (2004) Formation and stability of schwertmannite in acidic mining lakes. Geochim Cosmochim Acta 68(6):1185-1197

Ren HT, Jia SY, Liu Y, Wu SH, Han X (2012) Effects of Mn(II) on the sorption and mobilization of $\mathrm{As}(\mathrm{V})$ in the presence of hematite. J Hazard Mater 217-218:301-306

Rodier J (1975) Analysis of water. Wiley, NewYork, pp 176-177

Schwertmann U, Cornell RM (2008) Iron oxides in the laboratory. Wiley, New York, p 148

Smedley PL, Kinniburgh DG (2002) A review of the source, behaviour and distribution of arsenic in natural waters. Appl Geochem 17(5):517-568

Solozhenkin PM, Deliyanni EA, Bakoyannakis VN, Zouboulis AI, Matis KA (2003) Removal of As(V) ions from solution by akaganeite beta-FeO(OH) nanocrystals. J Min Sci 39(3):287-296

Tresintsi S, Simeonidis K, Vourlias G, Stavropoulos G, Mitrakas M (2012) Kilogram-scale synthesis of iron oxy-hydroxides with improved arsenic removal capacity: study of Fe(II) oxidationprecipitation parameters. Water Res 46(16):5255-5267

Wang WM, Song J, Han X (2013) Schwertmannite as a new Fentonlike catalyst in the oxidation of phenol by $\mathrm{H}_{2} \mathrm{O}_{2}$. J Hazard Mater 262:412-419

Webster JG, Swedlund PJ, Webster KS (1998) Trace metal adsorption onto an acid mine drainage iron(III) oxy hydroxy sulfate. Environ Sci Technol 32(10):1361-1368

World Health Organization (1993) Guidelines for drinking-water quality, vol. 1. Recommendations, 2nd edn. WHO, Geneva

Yamani JS, Miller SM, Spaulding ML, Zimmerman JB (2012) Enhanced arsenic removal using mixed metal oxide impregnated chitosan beads. Water Res 46(14):4427-4434

Yavuz CT, Mayo JT, Yu WW, Prakash A, Falkner JC, Yean S, Cong L, Shipley HJ, Kan A, Tomson M, Natelson D, Colvin VL (2006) Low-field magnetic separation of monodisperse $\mathrm{Fe}_{3} \mathrm{O}_{4}$ nanocrystals. Science 314(5801):964-967

Youngran J, Fan M, Van Leeuwen J, Belczyk JF (2007) Effect of competing solutes on $\operatorname{arsenic}(\mathrm{V})$ adsorption using iron and aluminum oxides. J Environ Sci 19(8):910-919

Zhang GS, Qu JH, Liu HJ, Liu RP, Li GT (2007) Removal mechanism of $\mathrm{As}(\mathrm{III})$ by a novel $\mathrm{Fe}-\mathrm{Mn}$ binary oxide adsorbent: oxidation and sorption. Environ Sci Technol 41(13): $4613-4619$ 